\title{
Clinical - epidemiological aspects and spatial analysis of leprosy relapses in an
}

\section{endemic area of Brazil}

\author{
Aspectos clínico-epidemiológicos e análise espacial das recidivas da hanseníase em uma área \\ endêmica do Brasil \\ Aspectos clínico-epidemiológicos y análisis espacial de las recaídas de lepra en una zona endémica \\ de Brasil
}

Thayane Santos Siqueira ORCID: https://orcid.org/0000-0001-8370-0544 Federal University of Sergipe, Brazil E-mail: thayane_siqueira@live.com

Ariel Oliveira Celestino ORCID: https://orcid.org/0000-0003-3907-187X Federal University of Sergipe, Brazil E-mail: biomedica.ariel@gmail.com

Alexrangel Henrique Cruz Santos ORCID: https://orcid.org/0000-0002-3667-5275 Federal University of Sergipe, Brazil E-mail: alex_rangel2020@hotmail.com

Mariana do Rosário Souza

ORCID: https://orcid.org/0000-0002-3139-8483 Federal University of Sergipe, Brazil

E-mail: enf.mariana.rosario@gmail.com

Amanda Francielle Santos

ORCID: https://orcid.org/0000-0001-7694-4604 Federal University of Sergipe, Brazil

E-mail: francyelly_amanda@hotmail.com

Beatriz Almeida Santos

ORCID: http://orcid.org/0000-0003-1527-615X

Federal University of Sergipe, Brazil

E-mail: Beatriz.enf12@gmail.com

Rosiene Batista Santos

ORCID: https://orcid.org/0000-0001-9584-6874

Universidade Tiradentes, Brazil

E-mail: rosiene.batista@souunit.com.br

Layanne Barbosa dos Santos

ORCID: https://orcid.org/0000-0002-2846-1082

Universidade Tiradentes, Brazil

E-mail: layanne.barbosas@gmail.com

Luciene Barbosa

ORCID: https://orcid.org/0000-0003-2026-994X

Federal University of Sergipe, Brazil

E-mail: lucienebarb@bol.com

Allan Dantas dos Santos

ORCID: https://orcid.org/0000-0002-6529-1887 Federal University of Sergipe, Brazil

E-mail: allanufs@hotmail.com

José Rodrigo Santos Silva

ORCID: https://orcid.org/0000-0002-1918-7122 Federal University of Sergipe, Brazil

E-mail: rodrigo.ufs@gmail.com

Ítalo Fernando Lisboa de Melo

ORCID: https://orcid.org/0000-0002-1754-8561

Universidade Federal de Sergipe, Brazil

E-mail: italo-lisboa@hotmail.com

\begin{abstract}
Objective: to analyze the trend, spatial distribution and factors associated with leprosy recurrence in Sergipe. Methods: this is a population-based ecological study, using spatial analysis and logistic regression techniques. Data from all leprosy recurrences reported to SINAN (Notifiable Diseases Information System) in the state of Sergipe,
\end{abstract}


Brazil, were used from 2007 to 2017. Results: there was a tendency for an increase in recurrences in the period from 2011 to 2017: APC: 14.69 (p-value = 0.003). The recurrence incidence map showed a heterogeneous behavior, with the Moran index $(\mathrm{I}=0.16$; p-value: 0.0159). The multivariate analysis showed a higher risk of recurrence in adults $(\mathrm{aOR}=2.81)$ and young adults $(\mathrm{aOR}=2.85)$ Conclusion: the risk factors associated with the appearance of recurrences are: the age group, the zone, the operational classification, the clinical form and the degree of disability.

Keywords: Spatial analysis; Epidemiology; Leprosy; Public health; Communicable diseases.

\section{Resumo}

Objetivo: analisar a tendência, a distribuição espacial e os fatores associados à recorrência da hanseníase em Sergipe. Métodos: trata-se de um estudo ecológico de base populacional, com o uso de técnicas de análise espacial e regressão logística. Foram utilizados dados de todas as recidivas de hanseníase notificadas ao SINAN (Sistema de Informação de Agravos de Notificação) do estado de Sergipe, Brasil, de 2007 a 2017. Resultados: Ocorreu uma tendência de aumento das recorrências da hanseníase no período de 2011 a 2017: APC: 14,69 (p-valor = 0,003). O mapa de incidência de recidivas apresentou comportamento heterogêneo, com o índice de Moran $(I=0,16$; $p$-valor: 0,0159$)$. A análise multivariada mostrou maior risco de recorrência em adultos $(\mathrm{aOR}=2,81)$ e adultos jovens $(\mathrm{aOR}=2,85)$ Conclusão: os fatores de risco associado ao aparecimento de recidivas são: a faixa etária, a zona, a classificação operacional, a forma clínica e o grau de incapacidade.

Palavras-chave: Análise espacial; Epidemiologia; Hanseníase; Saúde pública; Doenças transmissíveis.

\section{Resumen}

Objetivo: analizar la tendencia, distribución espacial y factores asociados a la recurrencia de la lepra en Sergipe. Métodos: se trata de un estudio ecológico de base poblacional, utilizando técnicas de análisis espacial y regresión logística. Se utilizaron los datos de todas las recurrencias de lepra reportadas al SINAN (Sistema de Información de Enfermedades Notificables) del estado de Sergipe, Brasil, de 2007 a 2017. Resultados: hubo una tendencia a aumentar las recurrencias en el período de 2011 a 2017: APC: 14,69 (valor de p =0,003). El mapa de incidencia de recurrencia mostró un comportamiento heterogéneo, con el índice de Moran $(\mathrm{I}=0,16$; p-valor: 0,0159). El análisis multivariado mostró mayor riesgo de recurrencia en adultos $(\mathrm{ORa}=2,81)$ y adultos jóvenes $(\mathrm{ORa}=2,85)$ Conclusión: los factores de riesgo asociados a la aparición de recidivas son: grupo de edad, zona, clasificación operativa, forma clínica y grado de discapacidad.

Palabras clave: Análisis espacial; Epidemiología; Lepra; Salud pública; Enfermedades contagiosas.

\section{Introduction}

In 1986, there was a significant reduction in the prevalence of leprosy worldwide with the establishment of multidrug therapy (MDT) in 1986. However, leprosy still remains endemic in some developing countries. (Ferreira et al., 2010; Santos et al., 2019). According to data from the World Health Organization (WHO), in Brazil in 2017, 26,875 new cases of the disease were detected, thus occupying an unfavorable position in the global scenario, second only to India. The same is true for disease recurrences, WHO data show that the country holds $49.8 \%$ of all leprosy cases in the world.(Gonçalves et al., 2019)

According to Bona et al. (2019) recurrence is the main indicator of ineffectiveness of the leprosy control program, as its increase may be subject to failures in the treatment of the disease. The ineffective therapeutic regimen, mainly caused by irregular dosage, time and the intake of medications, can compromise the cure, stimulating the occurrence of recurrent cases of the disease (Almeida et al., 2018).Another relevant point in the context of relapses is the monitoring of individuals after discharge, considering the reality of the services offered by the Unified Health System (SUS); the healthcare professional is limited to the assessment of the physical context in the definition of the degree of disability and during the (MDT)( de Souza et al., 2018).

In this scenario, questions are raised about the effectiveness of the leprosy control program based on the new guidelines of the Ministry of Health (MS)(Barbosa et al., 2014). Among the quality indicators of health services is the assessment of reported cases of recurrences in the year, noting that this indicator was incorporated into the guidelines of the Ministry of Health in 2016, with the objective of identifying and monitoring municipalities that fail in the treatment of the disease (Gonçalves et al., 2019; Melo et al., 2014). 
A study by Santos et al. (2019), analyzed the trend and the spatial distribution of leprosy in the state of Sergipe, from 2002 to 2015. In this research, one of the results that called attention was a high detection rate of new cases with grade 2 disability(da Silva et al., 2020). The increase in this indicator in the aforementioned historical series may be linked not only to failure in early diagnosis, but also in the operationalization of the health system, with regard to the monitoring of these individuals during treatment and in the post-discharge by cure (Alencar et al., 2012).

It should be noted, then, the need to research how the quality indicators of leprosy health services, among which the return rates, are affecting the permanence or alteration of the disease in the state. Studies that address the variables involved in the recurrences are necessary, as well as spatial approaches that show how these cases are distributed in the territory; the analyzes assist managers in evaluating health programs and improving results in the treatment of leprosy. Therefore, the present study aims to analyze the trend, spatial distribution and factors associated with leprosy recurrence in Sergipe.

\section{Methodology}

\section{Study design}

This is an ecological population-based study of the retrospective time-series type, using techniques of spatial analysis and bivariate and multivariate logistic regression. For this study, data from all cases of leprosy recurrences notified by the health centers of the municipalities to the SINAN (Information System on Notifiable Diseases) in the state of Sergipe, Brazil, from 2007 to 2017, were used. This system consists of a database of the Secretariat of Health of all states in Brazil, to report information on sociodemographic and clinical characteristics and the address of mandatory reporting diseases(Santos et al., 2019). The study took place in the state of Sergipe (Figure 1). It is one of the nine states located in the Northeast of Brazil; whose capital city is Aracaju. It is the smallest Brazilian state with a territory of $21,962.10 \mathrm{~km}^{2}$. In its administrative political organization, it has 75 municipalities grouped in three mesoregions and 13 microregion (IBGE, 2019).

Figure 1. Map of Brazil with emphasis on the Northeast region and the state of Sergipe.

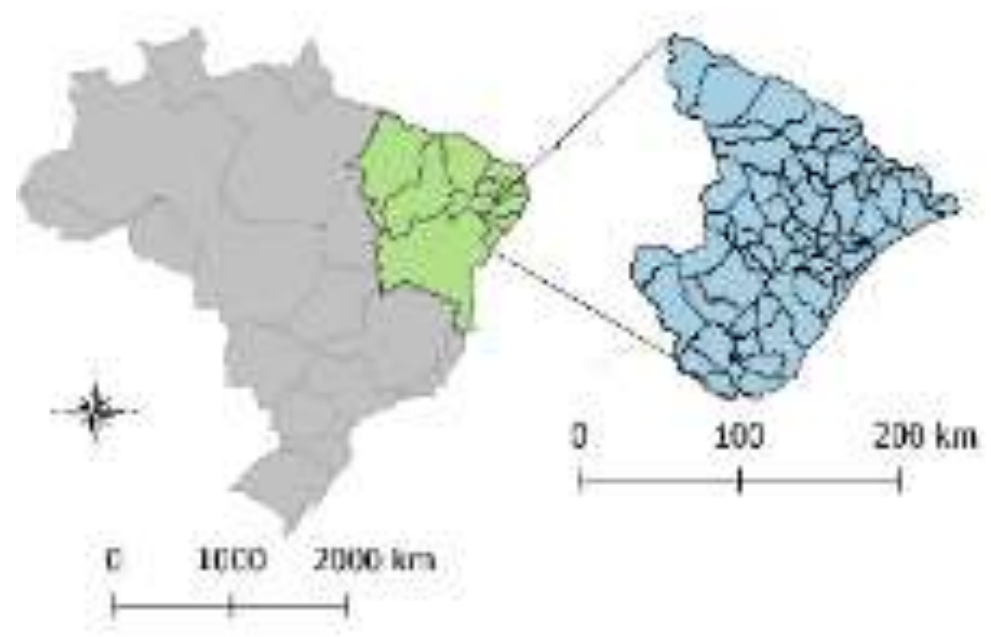

Source: Authors.

For the analysis of the temporal trend in recurrence, the proportion of recurring cases among the ones reported in the year was calculated with the formula described by the number of reported cases of leprosy recurrences divided by the total number of cases reported in the year x 100 thousand. This formula is calculated based on the "Guidelines for surveillance, care and elimination of leprosy as a public health problem" (Brazil, 2016 A). Polynomial regression was used to calculate the 
annual variation of the indicator, between 2007 and 2017. This method of analysis consists of a segmented linear regression, using dummy variables, to identify points where there is a change in the trend and estimate the Annual Percentage Change (APC), and the Average Annual Percentage Change (AAPC) considering the entire period of the series with a 95\% confidence interval (Monteiro et al., 2015).

\section{Spatial analysis}

The maps were constructed with the proportion of recurrent cases in each municipality. Since this operational indicator is recent, there are still no classification criteria defined by the Ministry of Health. To solve this problem, a stratification was proposed to Sergipe regarding recurrences using the K-means non-hierarchical clustering technique and the Hartigan-Wong algorithm. Hence, the municipalities were classified with low incidence: from 0 and 1.49; average: from 1.50 to 4.49 ; high: from 4.50 to 9.99; and very high: cases greater than or equal to 10 (Hair et al., 2019)

The spatial distribution was performed by the Global Moran's I, assuming the matrix of closest neighbors as a similarity metric. The index was used to show the degree of spatial autocorrelation, in which the values range from -1 to 1 ; positive values indicate direct correlation and negative values demonstrate inverse correlation, that is, dissimilarity between neighbors. The value zero indicates that there is no spatial dependence (Pinheiro et al., 2018).

After verifying the global autocorrelation, we proceed to the local spatial analysis (LISA- Local Indicators of Spatial Association) in order to quantify the degree of spatial association to which each location of the sample set is submitted according to a neighborhood model, allowing to infer local patterns of the spatial distribution of the analyzed variables. From Moran scatter plot for the identification of critical or transition areas, the value of each municipality is compared to the values of neighboring municipalities (Hair et al., 2019).

The generated quadrants were interpreted as follows: Q1- High/High (positive values and positive means); Q2Low/Low (negative values and negative means); Q3-High/Low (positive values and negative means); Q4- Low/High (negative values and positive means). LISA Map is based on the Local Moran's I for the identification of different patterns of statistical significance (non-significant, significance of 5\%,1\% and 0.1\%). Local Moran is a decomposition of Global Moran, in which it is possible to elaborate an analysis of the local pattern of spatial data(Oliveira et al., 2015).

\section{Statistics analysis}

The variables selected for the analysis of the factors associated with recurrences were: sex, age group, race, schooling, zone, operational classification, clinical form, degree of disability and bacillocospy. The association of these variables with recurrence was verified using the chi-squared test and the odds ratio (Odds Ratio - OR). The significant variables in the bivariate analysis were utilized as independent in a logistic regression model to adjust the occurrence or not of recurrence. All statistical analyzes were performed using software R 3.6.1, and the level of significance adopted was 5\% (Boigny et al., 2019).

\section{Patient and public involvement statement}

There was no patient and public involvement in this study. The study was based on secondary data.

\section{Results}

In Sergipe, between 2007 and 2017, 228 new cases of leprosy relapse were totaled. The percentage of recurrences in the state varied during the period of the aforementioned historical series, as shown in (Figure 2). In 2007, the percentage was (7.3\%), in 2011 (2.8\%) and in 2017 (7.6\%). For this indicator, two trends were observed: a decreasing one from 2007 to 2011 
(APC: -20.80; IC-30.14; -11.46; p-value = 0.008) and another increasing from 2013 to 2017 (APC: 14, 69; CI: 8.28; 21.31; pvalue $=0.003)$.

Figure 2. Percentage of cases of leprosy relapses by year of detection, in the period 2007-2017.

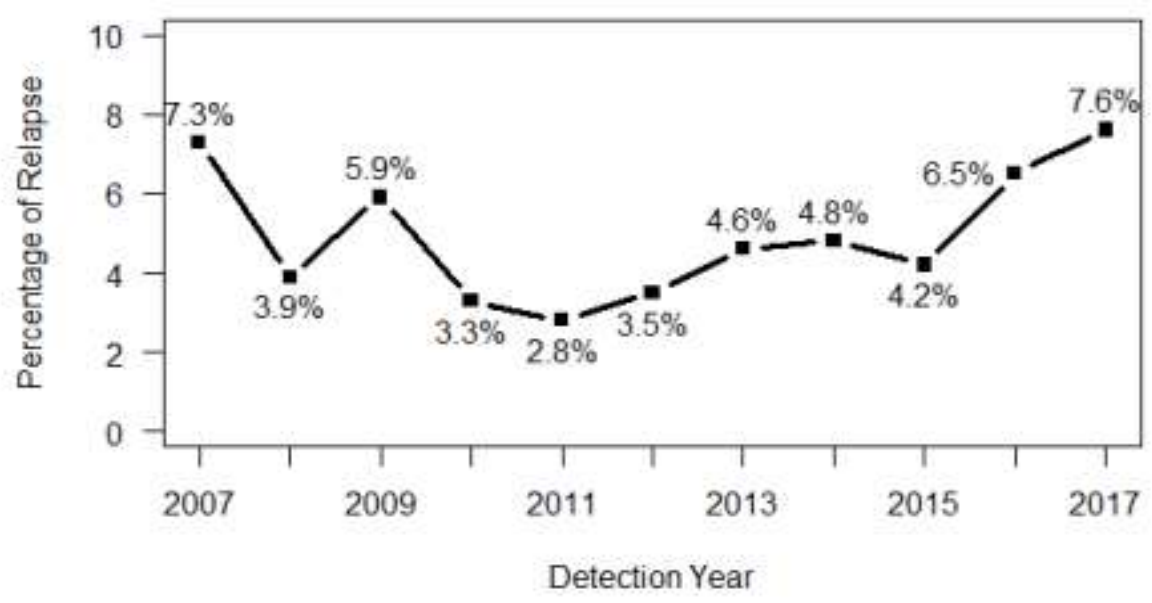

Source: Authors.

According to the map of the recurrent incidences, a heterogeneous behavior is observed in (Figure 3 ) for cases in the state, thus presenting, according to the parameters, 8 (10.67\%) municipalities with a very high incidence; 13 (17.33\%) high; average $16(21.33 \%)$ and $38(50.67 \%)$ with low incidence. The Moran's I was calculated showing positive spatial autocorrelation, $(I=0.16$; p-value $=0.0159)$. It can be seen from the Lisa map and the Moran map that 4 municipalities presented positive spatial correlation for the Q1 quadrant (High-High), being represented by the municipalities of Nossa Senhora Aparecida, Frei Paulo, Macambira and São Domingos. These municipalities are located in the Agreste and Alto Sertão Sergipano.

Figure 3. Spatial distribution of leprosy recurrences in Sergipe from 2007 to 2017. (A) Incidence of leprosy recurrences; (B) LISA map- Regions with significantly different local correlation; (C) MORAN map- results of local Moran index (BoxMap)/ in Q1 and Q2, the spatial association is positive/ in Q3 and Q4, the spatial.
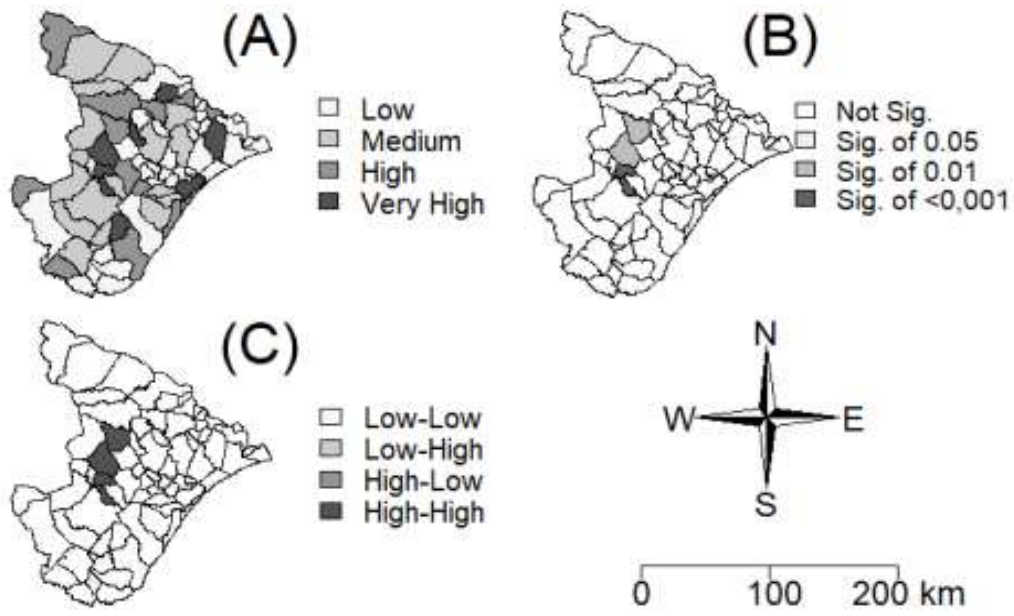

Source: Authors.

For all cases, the odds ratio (Odds Ratio - OR) was calculated. The sociodemographic and clinical factors of leprosy were taken as the basis for assessing the odds ratio as shown in (Table 1). The chance of recurrence regarding gender (p-value $=0.0846 ;$ OR: 0.78$)$, and race $(p=0.3665 ; \mathrm{OR}=1.19)$ did not obtain statistical significance. Concerning the age group, the 
young adult population $96(5.14 \%)$ and the adult $73(5.22 \%)$ were three times more likely to have recurrences ( $\mathrm{p}=0.0006$; OR $=3.00 ;$ OR $=3.04$ ) respectively, when compared to children under 15 years old. When observing schooling, illiterate people, with complete or incomplete elementary education, and people with secondary education, were twice as likely to have recurrences when compared to those with higher education (Table 1).

The rural zone was considered a place of protection regarding recurrences $(\mathrm{p}=0.0019 ; \mathrm{OR}=0.54)$ when compared to the urban area. About clinical variables, multibacillary individuals are more likely to have recurrences $(p=0.001$; OR $=1.85)$ when compared to paucibacillary ones. For the clinical forms, patients with the Borderline type present 1.67 chances of having recurrences $(\mathrm{p}=0.0176$; OR $=1.67)$, when compared to those who presented the tuberculoid and Lepromatous clinical form. People with grade 2 level of physical disability are more likely to have recurrences $(\mathrm{p}=0.0270 ; \mathrm{OR}=1.70)$ when compared to the grade 2. Bacilloscopy was not significant $(\mathrm{p}=0.581)$ (Table 1$)$.

Table 1. Chance ratio (aOR) of leprosy recurrence in Sergipe, according to sociodemographic and clinical characteristics from 2007 to 2017.

\begin{tabular}{|c|c|c|c|c|}
\hline \multirow{2}{*}{ Variable/Category } & \multicolumn{2}{|c|}{ Leprosy Recurrence } & \multirow{2}{*}{ OR (IC 95\%) } & \multirow{2}{*}{ P-value } \\
\hline & Yes & No & & \\
\hline \multicolumn{5}{|l|}{ Gender } \\
\hline Female & $97(3.72)$ & $2509(96.28)$ & $0.78(0.60 ; 1.02)$ & NS* \\
\hline Male & $131(4.71)$ & $2653(95.29)$ & 1.00 & \\
\hline \multicolumn{5}{|l|}{ Age group } \\
\hline Elderly & $35(3.01)$ & $1129(96.99)$ & $1.75(0.74 ; 4.14)$ & 0.0006 \\
\hline Adult & $73(5.22)$ & $1326(94.78)$ & $3.04(1.34 ; 6.94)$ & \\
\hline Young Adult & $96(5.14)$ & $1771(94.86)$ & $3.00(1.33 ; 6.79)$ & \\
\hline Young & $18(2.95)$ & $592(97.05)$ & $1.72(0.69 ; 4.30)$ & \\
\hline Under 15 years & $6(1.71)$ & $344(98.29)$ & 1.00 & \\
\hline \multicolumn{5}{|l|}{ Race } \\
\hline Black/Browns /Indigenous & $180(4.40)$ & $3907(95.60)$ & $1.19(0.84 ; 1.67)$ & NS* \\
\hline White/Yellow & $43(3.74)$ & $1107(96.26)$ & 1.00 & \\
\hline \multicolumn{5}{|l|}{ Schooling } \\
\hline Illiterate & $20(3.62)$ & $532(96.38)$ & $2.10(0.73 ; 6.08)$ & 0.0176 \\
\hline Elementary School & $119(4.19)$ & $2718(95.81)$ & $2.43(0.91 ; 6.53)$ & \\
\hline High school & $40(4.81)$ & $791(95.19)$ & $2.79(1.01 ; 7.72)$ & \\
\hline University education & $4(1.72)$ & $228(98.28)$ & 1.00 & \\
\hline \multicolumn{5}{|l|}{ Region } \\
\hline Periurban & $7(8.97)$ & $71(91.03)$ & $1.94(0.95 ; 4.00)$ & 0.0019 \\
\hline Countryside & $23(2.49)$ & $902(97.51)$ & $0.54(0.35 ; 0.83)$ & \\
\hline Urban & $185(4.62)$ & $3823(95.38)$ & 1.00 & \\
\hline \multicolumn{5}{|c|}{ Operational Classification } \\
\hline Multibacillary & $152(5.36)$ & $2682(94.64)$ & $1.85(1.40 ; 2.45)$ & 0.0001 \\
\hline Paucibacillary & $76(2.97)$ & $2479(97.03)$ & 1.00 & \\
\hline \multicolumn{5}{|l|}{ Clinical form } \\
\hline Lepromatous & $58(4.71)$ & $1173(95.29)$ & $1.45(0.98 ; 2.16)$ & 0.0176 \\
\hline Borderline & $66(5.43)$ & $1150(94.57)$ & $1.67(1.14 ; 2.47)$ & \\
\hline Tuberculoid & $45(3.42)$ & $1271(96.58)$ & $1.05(0.69 ; 1.61)$ & \\
\hline Indeterminate & $39(3.24)$ & $1164(96.76)$ & 1.00 & \\
\hline \multicolumn{5}{|c|}{ Level of physical disability } \\
\hline G2 & $26(5.91)$ & $414(94.09)$ & $1.70(1.12 ; 2.57)$ & 0.0272 \\
\hline G1 & $49(4.53)$ & $1033(95.47)$ & $1.30(0.94 ; 1.81)$ & \\
\hline Zero & $109(3.48)$ & $3022(96.52)$ & 1.00 & \\
\hline \multicolumn{5}{|l|}{ Bacilloscopy } \\
\hline Positive & $69(4.77)$ & $1379(95.23)$ & $1.11(0.80 ; 1.55)$ & $\mathrm{NS}^{*}$ \\
\hline Negative & $80(4.30)$ & $1779(95.70)$ & 1.00 & \\
\hline
\end{tabular}


*It is not significant. Source: Authors.

Adjustments were made to logistic regression models, assuming relapse as a dependent variable (adopting a value of 1 for cases in which there were relapses). The independent variables in each model were significant in the previous bivariate tests. The references adopted as basis were the same used in the previous tests.; the interpretation was made according to the Odds Ratio (OR) and the difference is that we consider the multiple variation of all independent variables, and their influence together on the dependent variables (Table 2).

The multivariate analysis showed a higher risk of recurrence on adults $(\mathrm{OR}=2.81)$ and young adults $(\mathrm{OR}=2.85)$ compared to those younger than 15 years. The elderly, on the other hand, did not present a significant difference in comparison with those younger than 15 years (Table 2). Living in the rural area was considered a protective factor against recurrences of the disease $(\mathrm{OR}=0.52)$, when compared to the urban area. Individuals with the multibacillary clinical form have a higher chance of recurrences $(\mathrm{OR}=2.77$ ), compared to paucibacillary, which reinforces the result presented in the bivariate analysis (Table 2).

The clinical form of the disease, as observed in previous tests, is related to leprosy recurrence. However, when analyzed together with other variables, it was not significant. It was observed, then, the existence of a higher risk for recurrences in patients with grade 2 of disability $(\mathrm{OR}=1.64)$, as pointed out in the bivariate analysis carried out previously (Table 2). In other words, we can say that the age group, the zone, the operational classification and the level of disability were more important in the risk analysis process for recurrence compared to the clinical form of the disease.

Table 2. Multivariate analysis of the association between socioeconomic and clinical risk variables and leprosy recurrences.

\begin{tabular}{ccccc}
\hline Variables & Estimate & OR $($ IC 95\%) & S.E. & P-value \\
\hline Intercept & -4.52 & & 0.53 & 0,0000 \\
Age Group (Elderly) & 0.47 & $1.60(0.61 ; 5.52)$ & 0.55 & $* \mathrm{NS}$ \\
Age Group (Adult) & 1.03 & $2.81(1.12 ; 9.39)$ & 0.53 & 0.0505 \\
Age Group (Young Adult) & 1.05 & $2.85(1.16 ; 9.46)$ & 0.52 & 0.0449 \\
Age Group (Youth) & 0.73 & $2.08(0.74 ; 7.38)$ & 0.57 & $* \mathrm{NS}$ \\
Region (Periurban) & 0.51 & $1.67(0.57 ; 3.89)$ & 0.48 & $* \mathrm{NS}$ \\
Region (Rural) & -0.65 & $0.52(0.30 ; 0.85)$ & 0.26 & 0.0132 \\
Operational Classification & 1.02 & $2.77(1.38 ; 5.18)$ & 0.33 & 0.0024 \\
(Multibacillary) & -0.59 & $0.56(0.27 ; 1.22)$ & 0.39 & $* \mathrm{NS}$ \\
Clinical Form (Lepromatous) & -0.19 & $0.82(0.41 ; 1.78)$ & 0.37 & $* \mathrm{NS}$ \\
Clinical Form (Boderline) & 0.21 & $1.23(0.75 ; 2.06)$ & 0.26 & $* \mathrm{NS}$ \\
Clinical Form (Tuberculoid) & 0.21 & $1.24(0.84 ; 1.80)$ & 0.19 & $* \mathrm{NS}$ \\
Grade of physical disability (G1) & 0.50 & $1.64(0.98 ; 2.66)$ & 0.25 & 0.0510 \\
Grade of physical disability (G2) & &
\end{tabular}

*It is not significant. Source: Authors.

\section{Discussion}

Operational health indicators are of great relevance to assess the quality of leprosy services, among them, the research stuck to the proportion of reported recurrence cases per year. Sergipe showed an increasing trend of leprosy recurrences from 2011 to 2017. For Simionato de Assis et al. (2018), the increase in the number of recurrences may be directly related to the failure to adhere to polychemotherapy treatment. Another study by Bona et al. (2015) reiterates the aforementioned attached idea, and attributes the appearance of recurrences in certain locations to factors such as bacillary resistance, acquired through 
drug resistance and errors in the operational classification adopted by the Organization World Health Organization (WHO). In bacillary resistance, the bacteria can survive adverse situations, developing getaway mechanisms to escape the action of drugs.

It is noted that there is a decreasing trend at the national level of the incidence rate of leprosy in the general population, in those under 15 years old and in the rate of new cases with grade 2 of disability(Bona et al., 2015). These indicators reflect an effectiveness in monitoring the progress of leprosy elimination by the Family Health Strategy (FHS), responsible for the active search for leprosy patients (Brito et al., 2016). It is concatenated that, early diagnosis mitigates the appearance of complications leprosy, such as grade 2 of physical disability(C. D. F. de Souza et al., 2019). These data reinforce other research conducted in Sergipe, in which the same indicators were evaluated, and it can be identified that there was a reduction in the incidence rates in the state (C. L. M. Silva et al., 2017).

It is interesting to observe that, while there is an effectiveness of early diagnosis of the disease, this study on relapses reveals a weakness in comprehensive care for people during the MDT post-discharge period. The National Leprosy Control Plan (NLCP) has been in vogue since 2010 (in Brazil), however, a huge gap between actions aimed at leprosy during the period of illness and the post-cure one is accentuated(Moreira et al., 2018).We emphasize the need for new approaches to patient follow-up in post-discharge, expanding the concept of cure, in addition to interrupting the chain of transmission, since it has been identified that there is a potential risk of developing both reactive episodes in post-discharge and relapses (Oliveira et al., 2015).

As mentioned in the results of the spatial analysis, the municipalities that showed a positive correlation for the Q1 quadrant (High-High), are located in the Agreste region and in the Alto Sertão Sergipano of the state of Sergipe. According to Alencar et al. (2012) the spatial analysis of health events aims to identify geographic patterns through risk maps and to point out areas of greater severity and to facilitate the planning of public health interventions. Demarcated areas on the maps denote the need for a forecasting system for effective leprosy, which is not based only on the notification of confirmed cases, but also on the monitoring and planning of promotional actions aimed at assisting cases of cure.

The present study analyzed the risk factors associated with recurrences in the sociodemographic and clinical realms. Although the variable sex was not significant in this study, other studies show that men are more likely to have recurrences when compared to women; as shown in the study by Almeida et al. (2018), that analyzed the cases of leprosy recurrences in the state of Bahia, in the period from 2005 to 2015. The descriptive results of this research demonstrated that men represented $61 \%$ of the recurrent cases. In the same study, the author attributes a high prevalence of men to less demand for health services and greater exposure or social contact to risky environments.

Regarding education, this research endorses the results of other studies, thus, individuals with less education have more chances of recurrence when compared to the ones with higher education(Ribeiro et al., 2018). People with low education have difficulties to understand the disease, as well as prevention, being more likely to abandon treatment and develop recurrences. Such scenario contributes to a greater exposure of individuals more vulnerable to the disease, once their understanding becomes limited (Boigny et al., 2019).

It was noted that the young adult and adult age groups were more likely to have recurrences when compared to the elderly group. This data draws attention, since the elderly due to the senescence process would present a marked decrease in the activity of the immune system; which would predispose the appearance of recurrences more easily. Nevertheless, the adult age group is the most cited in the majority of studies, which attributes this greater risk to the fact that these individuals are considered economically active and have greater contact with the bacillus in large urban centers(C. L. M. Silva et al., 2017).

The rural area was considered as a protective factor against the onset of leprosy, given the high rates of people affected by leprosy are in large urban centers(Bona et al., 2015). The referred data reflect the map of the incidence of recurrences in Sergipe, where: Aracaju, São Cristóvão, Itabaiana, Socorro and Barra dos Coqueiros were the municipalities 
that had the highest incidence of recurrences in the state. Most leprosy patients are from peripheral regions, where people live under precarious conditions associated with a low socioeconomic and cultural profile.Thus, it is of singular importance to have a different look at these places that may present individuals with disease recurrence after hospital discharge(Simionato de Assis et al., 2018).

Concerning the clinical variables, the multibacillary operational classification and the degree of physical disability were considered risk variables for the appearance of recurrences in both the bivariate and multivariate analysis. This result suggests that the late diagnosis is closely linked to the complications of leprosy as grade 2 disability and the very appearance of relapses - the high bacillary load is a contributory factor for bacterial resistance (Simionato de Assis et al., 2018). Primary Health Care is the main gateway for Brazilian Unified Health System (SUS). Many professionals are not prepared enough to deal with complications caused by the disease, this weakens the health service aimed at this population(Ediela et al., 2012).

The problem of leprosy is complex and multifaceted. The present study restates the importance of monitoring priority groups for the circumstances of recurrences; and these groups are adults with low education, living in precarious conditions, containing multibacillary classification and grade 2 disability. Based on this analysis, the study raises questions about the effectiveness and monitoring of primary care for groups that present conditions of greater social inequality, often marginalized by society and without any degree of education for the recognition of signs and symptoms of disease relapses.

Therefore, effective disease control requires an integrated approach as recommended by the Unified Health System, which offers greater quality, accessibility, better cost and long-term effectiveness(E. A. de Souza et al., 2018). Leprosy elimination activities should be based on the Family Health Strategy (FHS), aiming at the early diagnosis and treatment of the disease, and differentiated monitoring after discharge. The primary care network must be integrated with the reference network, mainly in the elucidation and resolution of recurrent cases(Brito et al., 2016).

Our study presented some limitations, among them, the fact that secondary data from SINAN were used. It is worth mentioning that the quality of the secondary data provided will not always be applied to reality, given the large underreporting cases. Nevertheless, leprosy is a notifiable disease in Brazil and, as legislation requires, all cases of leprosy must be notified in the registered system(Santos et al., 2019). In addition, because it is an ecological study, it is necessary to be careful with this type of approach and with ecological fallacy, which occurs when an association observed at an assembled level is transported to an individual level. Despite the mentioned exceptions, this study, differently from the others existing in the literature, managed to aggregate several aspects related to recurrences in the State of Sergipe (Pinheiro et al., 2018).

\section{Conclusion}

The study presented new approaches and discussions regarding the operationalization of leprosy care actions and services, focusing on recurrences as a major factor for maintaining the disease in the territory. It is possible to notice from this research, an increasing of the relapses rates in the state; with a considerable concentration of cases in Agreste and Alto Sertão Sergipano, thus reinforcing a greater attention of these regions by the municipal managers.

A different look at the risk factors associated with the appearance of recurrences is also advocated. Among the risks, our study highlighted the age group, the zone, the operational classification, clinical form and the degree of disability, as relevant to the triggering of recurrent episodes after discharge for cure. The definition of priority groups is important for the delimitation of new strategies that aim at a differentiated monitoring of these individuals by the health system, both during the treatment and in the post discharge due to cure. This study opens up possibilities for further research to be carried out, aiming at the elaboration of follow-up protocols in leprosy post-discharge by cure to groups considered strategic. 


\section{References}

Alencar, C. H., Ramos, A. N., dos Santos, E. S., Richter, J., \& Heukelbach, J. (2012). Clusters of leprosy transmission and of late diagnosis in a highly endemic area in Brazil: Focus on different spatial analysis approaches. Tropical Medicine and International Health, 17(4), 518-525. https://doi.org/10.1111/j.1365-3156.2011.02945.x

Almeida, K. T., Menezes, A. M. F., Alves, K. A. N., Carmo Filho, J. R., \& Nascimento Costa, A. K. A. (2018). Leprosy relapse between the years $2005-2015$. Revista de Enfermagem UFPE, 12(10), 2528-2534.

Barbosa, J. C., Ramos Junior, A. N., Alencar, O. M., Pinto, M. S. P., \& Castro, C. G. J. de. (2014). Atenção pós-alta em hanseníase no Sistema Único de Saúde: aspectos relativos ao acesso na região Nordeste. Cadernos Saúde Coletiva, 22(4), 351-358. https://doi.org/10.1590/1414-462x201400040008

Brazil (2016) A, Ministry of Health. Secretariat of Health Surveillance. Guidelines for surveillance, care and elimination of Hansen's disease as a public health problem: technical-operational manual. https://www.paho.org/pt/brasil

Boigny, R. N., de Souza, E. A., Romanholo, H. S. B., de Araújo, O. D., de Araújo, T. M. E., Carneiro, M. A. G., Grijó, M. D. F., Henz, N. de L. F. B., Dos Reis, A. da S., Pinto, M. S. A. P., Barbosa, J. C., \& Ramos, A. N. (2019). Persistence of leprosy in household social networks: Overlapping cases and vulnerability in endemic regions in Brazil. Cadernos de Saude Publica, 35(2), 1-14. https://doi.org/10.1590/0102-311x00105318

Bona, S. H., Silva, L. O. B. do V. e, Costa, U. A., Holanda, A. O. do N., \& Campelo, V. (2015). Recidivas de hanseníase em Centros de Referência de Teresina, Piaú, 2001-2008. Epidemiologia e Serviços de Saúde, 24(4), 731-738. https://doi.org/10.5123/s1679-49742015000400015

Brito, A. L., Monteiro, L. D., Ramos Junior, A. N., Heukelbach, J., \& Alencar, C. H. (2016). Tendência temporal da hanseníase em uma capital do Nordeste do Brasil: Epidemiologia e análise por pontos de inflexão, 2001 a 2012. Revista Brasileira de Epidemiologia, 19(1), 194-204. https://doi.org/10.1590/19805497201600010017

da Silva, C. R., Sampaio, L. H. F., de Souza, J. P. F., Caetano, G. T. P., \& Wastoswki, I. J. (2020). Epidemiological trends of leprosy in Goiás, Brasil. Ciencia e Saude Coletiva, 25(10), 3723-3730. https://doi.org/10.1590/1413-812320202510.31022018

de Souza, E. A., Ferreira, A. F., Boigny, R. N., Alencar, C. H., Heukelbach, J., Martins-Melo, F. R., Barbosa, J. C., \& Ramos, A. N. (2018). Leprosy and gender in Brazil: Trends in an endemic area of the Northeast region, 2001-2014. Revista de Saude Publica, 52, 1-12. https://doi.org/10.11606/S15188787.2018052000335

Ediela, E., Schlickman, D., \& Guerino, M. R. (2012). Relação entre o número de casos de hanseníase e o número de unidades básicas na cidade de Primavera do Leste-MT , Brasil Relationship between the number of cases of leprosy and the number of basic units in Primavera do. J Health Sci Inst, 30 (2), 150-155.

Ferreira, S. M. B., Ignotti, E., Senigalia, L. M., Silva, D. R. X., \& Gamba, M. A. (2010). Recidivas de casos de hanseníase no estado de Mato Grosso. Revista de Saúde Pública, 44(4), 650-657. https://doi.org/10.1590/s0034-89102010000400008

Hair, J. F, Black, W. C, Babin, B. J, Anderson, R. E, \& Tatham, R. L.(2019) Multivariate analysis of data. (6th ed.), Bookman

IBGE. - Brazilian Institute of Geography and Statistics. Cities @ Sergipe. https://www.ibge.gov.br/en/home-eng.html

Gonçalves, F. G., Belone, A. D. F. F., Rosa, P. S., \& Laporta, G. Z. (2019). Underlying mechanisms of leprosy recurrence in the Western Amazon: A retrospective cohort study. BMC Infectious Diseases, 19(1), 1-10. https://doi.org/10.1186/s12879-019-4100-6

Melo, S. L., Macedo, G. M. M. de, Pires, C. A. A., \& Cunha, M. H. C. M. da. (2014). Recidiva hansênica em área de alta endemicidade no Estado do Pará, Brasil. Revista Pan-Amazônica de Saúde, 5(3), 19-24. https://doi.org/10.5123/s2176-62232014000300003

Monteiro, L. D., Martins-Melo, F. R., Brito, A. L., Alencar, C. H., \& Heukelbach, J. (2015). Spatial patterns of leprosy in a hyperendemic state in Northern Brazil, 2001-2012. Revista de Saude Publica, 49. https://doi.org/10.1590/S0034-8910.2015049005866

Moreira, R. S., Costa, J. S., Moreira-junior, V. T., Aurélio, M., \& Góes, D. O. (2018). Original article Temporal trend of leprosy in Aracaju , Sergipe , Brazil Tendência temporal da hanseníase em Aracaju, Sergipe,

Oliveira, K. S. de, Souza, J. de, Campos, R. B., Zilly, A., \& Silva-Sobrinho, R. A. (2015). Avaliação dos indicadores epidemiológicos e operacionais para a hanseníase em municípios prioritários no estado do Paraná, 2001 a 2010. Epidemiologia e Serviços de Saúde, 24(3), 507-516. https://doi.org/10.5123/s167949742015000300016

Pinheiro, M. G. C., Miranda, F. A. N. de, Simpson, C. A., Carvalho, F. P. B. de, Ataide, C. A. V., \& Lira, A. L. B. de C. (2018). Compreendendo a "alta em hanseníase": uma análise de conceito. Revista Gaucha de Enfermagem, 38(4), e63290. https://doi.org/10.1590/1983-1447.2017.04.63290

Ribeiro, M. D. A., Silva, J. C. A., \& Oliveira, S. B. (2018). Epidemiologic study of leprosy in Brazil: reflections on elimination goals. Revista Panamericana de Salud Publica/Pan American Journal of Public Health, 42, 1-7. https://doi.org/10.26633/RPSP.2018.42

Santos, M. B., Dos Santos, A. D., Barreto, A. S., Souza, M. D. R., Goes, M. A. D. O., Barreto Alves, J. A., Barreto, I. D. C., Silva, J. R. S., De Oliveira, D. T., De Araújo, K. C. G. M., Duthie, M. S., \& De Jesus, A. R. (2019). Clinical and epidemiological indicators and spatial analysis of leprosy cases in patients under 15 years old in an endemic area of Northeast Brazil: An ecological and time series study. BMJ Open, 9(7). https://doi.org/10.1136/bmjopen-2018023420

Silva, C. L. M., Fonseca, S. C., Kawa, H., \& Palmer, D. D. O. Q. (2017). Spatial distribution of leprosy in Brazil: A literature review. Revista Da Sociedade Brasileira de Medicina Tropical, 50(4), 439-449. https://doi.org/10.1590/0037-8682-0170-2016

Simionato de Assis, I., Arcoverde, M. A. M., Ramos, A. C. V., Alves, L. S., Berra, T. Z., Arroyo, L. H., Queiroz, A. A. R. de, Santos, D. T. dos, Belchior, A. de S., Alves, J. D., Pieri, F. M., Silva-Sobrinho, R. A., Pinto, I. C., Tavares, C. M., Yamamura, M., Frade, M. A. C., Palha, P. F., Chiaravalloti-Neto, F., \& Arcêncio, R. A. (2018). Social determinants, their relationship with leprosy risk and temporal trends in a tri-border region in Latin America. PLoS Neglected Tropical Diseases, 12(4), 1-17. https://doi.org/10.1371/journal.pntd.0006407 
Research, Society and Development, v. 10, n. 10, e267101018761, 2021

(CC BY 4.0) | ISSN 2525-3409 | DOI: http://dx.doi.org/10.33448/rsd-v10i10.18761

Souza, C. D. F. de, Luna, C. F., \& Magalhães, M. de A. F. M. (2019). Transmissão da hanseníase na Bahia, 2001-2015: modelagem a partir de regressão por pontos de inflexão e estatística de varredura espacial. Epidemiologia e Servicos de Saude: Revista Do Sistema Unico de Saude Do Brasil, $28(1)$, e2018065. https://doi.org/10.5123/S1679-49742019000100015 